\title{
PENILAIAN PENERAPAN KONSEP LIVABLE SETTLEMENT DI PERMUKIMAN KOTA SURAKARTA
}

\author{
William Chrysostom Gonta ${ }^{1}$, Winny Astuti ${ }^{1}$, Ana Hardiana ${ }^{2}$ \\ ${ }^{1}$ Program Studi Perencanaan Wilayah dan Kota, Fakultas Teknik, Universitas Sebelas Maret \\ 2Program Studi Arsitektur, Fakultas Teknik, Universitas Sebelas Maret
}

\begin{abstract}
Abstrak
Permukiman adalah bagian dari lingkungan hunian yang terdiri atas lebih dari satu satuan perumahan yang mempunyai prasarana, sarana, utilitas umum, serta mempunyai penunjang kegiatan fungsi lain di kawasan perkotaan atau perdesaan. Konsep livable settlement merupakan suatu konsep tentang permukiman yang disesuaikan dengan aspek-aspek permukiman layak huni. Berdasarkan persepsi masyarakat, Kota Surakarta merupakan salah satu dari beberapa kota layak huni di Indonesia berdasarkan Most Liveable City Index (MLCI) Tahun 2017. Fakta di lapangan menunjukkan bahwa masih banyak permasalahan di dalam permukiman khususnya kawasan perkotaan Kota Surakarta. Tujuan dari penelitian untuk menganalisis tingkat kesesuaian dari permukiman Kota Surakarta berdasarkan aspek-aspek livable settlement. Metode yang digunakan dalam penelitian ini menggunakan metode teknik analisis skoring dan analisis deskriptif. Hasil penelitian menunjukkan bahwa permukiman Kota Surakarta mendekati sesuai dengan konsep livable settlement dengan skor sebesar $68,75 \%$. Komponen permukiman yang sudah sesuai dengan indikator layak huni di antaranya: kondisi bangunan, jalan lingkungan, air bersih, persampahan, pengelolaan air limbah, pengamanan bahaya kebakaran, kepadatan bangunan yang tidak tinggi, biaya hidup yang terjangkau, ketersediaan transportasi umum, aksesibilitas, dan tarif transportasi umum. Untuk komponen permukiman yang belum sesuai dengan indikator layak huni di antaranya: luas bangunan, ketersediaan ruang terbuka hijau publik, fungsionalitas ruang terbuka hijau publik, drainase lingkungan, dan jalur pedestrian yang belum aman.
\end{abstract}

Kata kunci: kawasan perkotaan; kesesuaian; komponen permukiman; livable settlement

\begin{abstract}
Settlements are part of a residential area consisting of more than one housing unit faclitated with infrastructure, facilities, public utilities, and supported by other functional activities in urban or rural areas. The concept of livable settlement is a concept of settlements that is adapted to aspects of habitable settlements. Based on public perception, Surakarta City is one among a few habitable cities in Indonesia based on the 2017 Most Livable City Index (MLCl). However, the field observation shows that many problems remain apparent in the Surakarta's settlement. Therefore, the study aims at analyzing the level of suitability of Surakarta's settlements based on livable settlement aspects. The study appliesquantitative method with scoring as technique ofanalysis combined with statistical descriptive analysis. The results show that the settlements of Surakarta is quite close to comply with the concept of livable settlement with a score of $68.75 \%$. Components of settlements that are in accordance with livable indicators are building conditions, environmental roads, clean water, solid waste, waste water management, safeguarding fire hazards, low building density, affordable living costs, availability of public transportation, accessibility, and public transportation rates. Whereas the components of settlements that are not yet fulfill the livable indicators are building area, availability of public green open space, public green open space functionality, environmental drainage, and unsafe pedestrian lanes.
\end{abstract}

Keywords: components of settlement; livable settlement; the suitability; urban areas

\section{PENDAHULUAN}

Permukiman merupakan suatu kawasan penting pada suatu kota karena masyarakat kota pada umumnya tinggal pada kawasan permukiman. Permukiman didominasi oleh rumah-rumah yang sebagian besar fungsinya adalah sebagai tempat tinggal dan tempat hunian. Selain itu untuk menunjang sistem permukiman, perlu adanya fasilitas-fasilitas yang dapat menunjang kegiatan dan aktivitas manusia yang ada di dalamnya. Untuk mendukung salah satu agenda Sustainable Development Goals (SDGs) yang disebutkan dalam agenda nomor 11 adalah sustainable cities and communities 
bahwasannya perlu pengembangan suatu permukiman agar kualitasnya lebih baik agar dapat menunjang dan membuat suatu kota untuk berkelanjutan. Tentunya masyarakat pasti menginginkan lingkungan yang layak huni dan bangunan yang nyaman untuk ditinggali. Maka dari itu konsep livable settlement digunakan untuk mengetahui apakah permukiman di Kota Surakarta sudah sesuai dengan konsep permukiman layak huni dan seberapa besar tingkat kesesuaiannya.

Kota Surakarta merupakan salah satu kota layak huni berdasarkan survei Ikatan Ahli Perencana (IAP) dalam Most Livable City Index (MLCI) Tahun 2017. Metode yang digunakan pada penilaian Most Livable City Index adalah berbasis pada persepsi warga kota yang sifatnya masih objektif, sehingga penilaian yang dilakukan belum menggambarkan kondisi dan fakta lapangan yang sesungguhnya. Bila melihat berdasarkan fakta yang berada di Kota Surakarta dan mengaitkan dengan permukiman layak huni, masih banyak terdapat berbagai isu dan permasalahan yang terjadi seperti di antaranya terdapat area permukimanpermukiman kumuh, masih banyak rumah tidak layak huni, dan fasilitas infrastruktur yang belum memadai. Tujuan dari penelitian untuk menganalisis tingkat kesesuaian dari permukiman Kota Surakarta berdasarkan aspek-aspek livable settlement. Dalam penelitian ini indikator layak huni yang digunakan mencakup keseluruhan masing-masing variabel dan subvariabel yang sudah dirumuskan. Variabel yang didapatkan mencakup 3 aspek utama yaitu aspek sosial, ekonomi, dan lingkungan.

\section{KAJIAN LITERATUR}

\subsection{LIVABLE SETTLEMENT}

Menurut UU No. 1 Tahun 2011 permukiman adalah bagian dari lingkungan hunian yang terdiri atas lebih dari satu satuan perumahan yang mempunyai prasarana, sarana, utilitas umum, serta mempunyai penunjang kegiatan fungsi lain di kawasan perkotaan atau perdesaan. Sedangkan konsep Livable Settlement atau konsep yang mengacu dan mengarah permukiman yang layak huni sebenarnya sudah diatur dalam beberapa program permerintah. Permukiman yang ada, khususnya permukiman pada lingkungan perkotaan harus dikembangkan kepada suatu tatanan layak huni. Adapun pengertian pengembangan permukiman RPIJM (Rencana Program Investasi Jangka Menengah) dari Direktorat Jenderal Cipta Karya Departemen Pekerjaan Umum 2006-2010 yaitu pengembangan permukiman baik di perkotaan maupun di perdesaan yang pada hakekatnya adalah untuk mewujudkan kondisi perkotaan dan perdesaan yang layak huni (livable), aman, nyaman, damai, sejahtera, dan berkelanjutan.

Konsep layak huni menurut Heylen (2006) adalah mengacu pada kondisi lingkungan fisik yang dilihat dari perspektif setiap masyarakat yang subjeknya adalah pada evaluasi kualitas pada kondisi perumahan. Kendati perspektif dan persepsi masingmasing individu dalam masyarakat bersifat objektif, maka pemahaman baru tentang permukiman layak huni dibutuhkan, baik pada campuran kualitatif dan indikator kuantitatif, untuk membuat perubahan yang sesuai dalam pengaturan mereka sendiri dan dalam dinamika informasi statis mengenai kebijakan ataupun praktik yang baik (Silas \& Ernawati, 2013).

\subsection{KOMPONEN LIVABLE SETTLEMENT}

Peraturan Menteri Pekerjaan Umum Nomor 22/PRT/M/2008 menjelaskan bahwa rumah layak huni adalah rumah yang memenuhi persyaratan keselamatan bangunan dan kesehatan penghuninya, serta kecukupan minimum luas bangunan. Bangunan hunian atau dalam kaitan disini adalah rumah tinggal menurut Undang-Undang No 1 Tahun 2011 adalah bangunan yang harus memiliki ukuran paling sedikit $36 \mathrm{~m}^{2}$. Untuk kondisi bangunan dalam SNI 03-1727-1989 dijelaskan bahwa struktur rumah atau tempat hunian harus kokoh dan merupakan bangunan permanen. Kriteria utama adalah durabilitas (keawetan) bahan bangunan sebagai material bangunan publik, serta penampilan yang sesuai dengan fungsi dan ekspresi yang diinginkan. Klasifikasi bahan materialnya dapat disimpulkan bahwa 3 struktur utama yang harus diperhatikan adalah lantai, dinding, dan atap rumah.

Untuk memilih sebuah tempat hunian, biasanya masyarakat tidak hanya melihat kondisi rumah itu sendiri sebagai bahan pertimbanagan, tetapi juga memperhatikan kelengkapan sarana dan prasarana penunjang di kawasan tersebut (Khadiyanto, 2015). Pada umumnya, manusia tidak akan berdiam diri tetapi akan melakukan segala bentuk aktivitas untuk melangsungkan kehidupannya. Aktivitas tersebut dapat berupa aktivitas sosial, ekonomi, dan lain sebagainya (Raditya, 2011). Jadi aktivitas 
sosial ekonomi harus didukung dengan lingkungan fisik yang memadai agar membentuk sebuah sinergitas dalam sebuah sistem permukiman

Dalam pelaksanaannya, Pemerintah Pusat melalui Kementerian Pekerjaan Umum dan Perumahan Rakyat, Direktorat Jenderal Cipta Karya telah mengeluarkan Surat Edaran Nomor 40/SE/DC/2016 tentang Pedoman Umum Program Kota Tanpa Kumuh (Kotaku). Dalam surat edaran tersebut dijelaskan tentang indikator permukiman layak huni dan berkelanjutan yaitu terkait fisik: kondisi bangunan hunian, jalan lingkungan, drainase lingkungan, penyediaan air bersih/minum, pengelolaan persampahan, pengelolaan air limbah, pengamanan bahaya kebakaran dan ruang terbuka publik.

Layak huni sendiri juga mengacu pada tingkat kenyamanan suatu permukiman untuk dapat ditinggali manusia. Tingkat kenyamanan permukiman dipengaruhi oleh liputan vegetasi, kepadatan bangunan, kondisi geometri bangunan, kondisi suhu udara, kelembapan udara (Helena \& Hidayati, 2016). Kepadatan bangunan juga sangat mempengaruhi ruang gerak dari individu atau kelompok dalam melakukan aktivitasnya, dan juga bila suatu permukiman memiliki kepadatan yang tinggi pasti akan memicu faktor timbulnya kekumuhan. Hal lain disampaikan oleh Furlan (2015) untuk meningkatkan kelayakan hidup, bentuk tata ruang lingkungan tempat tinggal harus dikombinasikan dengan ruang publik, desain lingkungan penggunaan campuran, sistem transportasi umum yang efisien, jaringan pejalan kaki. Itu semua akan berkontribusi untuk menciptakan rasa kebersamaan dan memperluas peluang untuk interaksi sosial yang pada akhirnya akan berkontribusi untuk meningkatkan livability.

Lebih lanjut Furlan (2016) menjelaskan bahwa lingkungan tempat tinggal yang dilengkapi oleh fasilitas-fasilitas khususnya ruang terbuka publik harus dapat mendorong interaksi sosial masyarakat. Selain itu kelebihan dan keuntungan dengan adanya fasilitas ruang terbuka publik tersebut antara lain untuk kesehatan, sarana pembelajaran, toleransi, solidaritas antar warga, dan ekonomi. Ruang-ruang ini juga dapat menawarkan peluang pembelajaran sosial yang cukup karena mereka dapat diakses secara universal: orang difasilitasi untuk secara langsung menghadapi orang lain dengan budaya dan kebiasaan yang berbeda. Ruang terbuka juga dapat menawarkan kesempatan untuk membangun rasa solidaritas di antara sesama warga, melalui pertemuan dan acara yang diselenggarakan seperti festival.

Selain dari segi sosial, livable settlement juga harus memperhatikan sisi ekonomi dari masyarakat tinggal. Pemenuhan akan kebutuhan sehari-hari bagi masyarakat sangatlah penting. Dijelaskan bahwa kinerja sosial dan produktivitas masyarakat di Indonesia berkaitan pula dengan tingkat daya beli masyarakat atau pendapatan yang pada umumnya masih rendah. Artinya, para konsumen masih berpikir pada taraf yang penting terjangkau kebutuhan mereka sehari-hari (Hendarti, 2006). Dijelaskan lebih lanjut (Maslow, 1994) kebutuhan sehari-hari merupakan psychological needs yaitu kebutuhan akan sandang, pangan, papan yang merupakan kebutuhan primer.

Menurut Luhst (1997) menyebutkan bahwa kualitas kehidupan yang berupa kenyamanan, keamanan dari suatu rumah tinggal sangat ditentukan oleh lokasinya, dalam arti daya tarik dari suatu lokasi ditentukan oleh dua hal yaitu lingkungan dan aksesibiltas. Aksesibilitas yang dimaksud adalah kemudahan masyarakat dalam mencapai transportasi umum yang gunanya memudahkan masyarakat untuk mencapai suatu tempat atau tujuan. Pendapat Tarigan (2012) bahwa tingkat akesibiltas salah satunya dipengaruhi oleh jarak. Kemudian untuk memudahkan masyarakat menjangkau transportasi umum pada suatu area jalan setidaknya memiliki jarak dari rumah 400 meter atau dengan waktu tempuh 5-20 menit sesuai (Perry, 1929). Faktor ekonomi bila dikaitkan dengan aksesibilitas adalah kemampuan untuk membayar biaya transportasi. Biaya transportasi dapat berpengaruh terhadap penentuan suatu lokasi tempat tinggal yang nyaman, juga melihat sarana transportasi umum yang dapat digunakan untuk menjangkau segala lokasi (Putri \& Jamal, 2014). Jadi keterjangkauan biaya transportasi akan memudahkan masyarakat dalam melakukan kegiatan dan aktivitasnya.

\section{METODE PENELITIAN}

\subsection{RUANG LINGKUP PENELITIAN}

Ruang lingkup wilayah pada penelitian berada pada permukiman Surakarta secara makro dengan ruang lingkup waktunya adalah menggunakan data-data terbaru. Statistik dan peta ruang lingkup penelitian dapat dilihat pada Gambar 1 dan Tabel 1: 


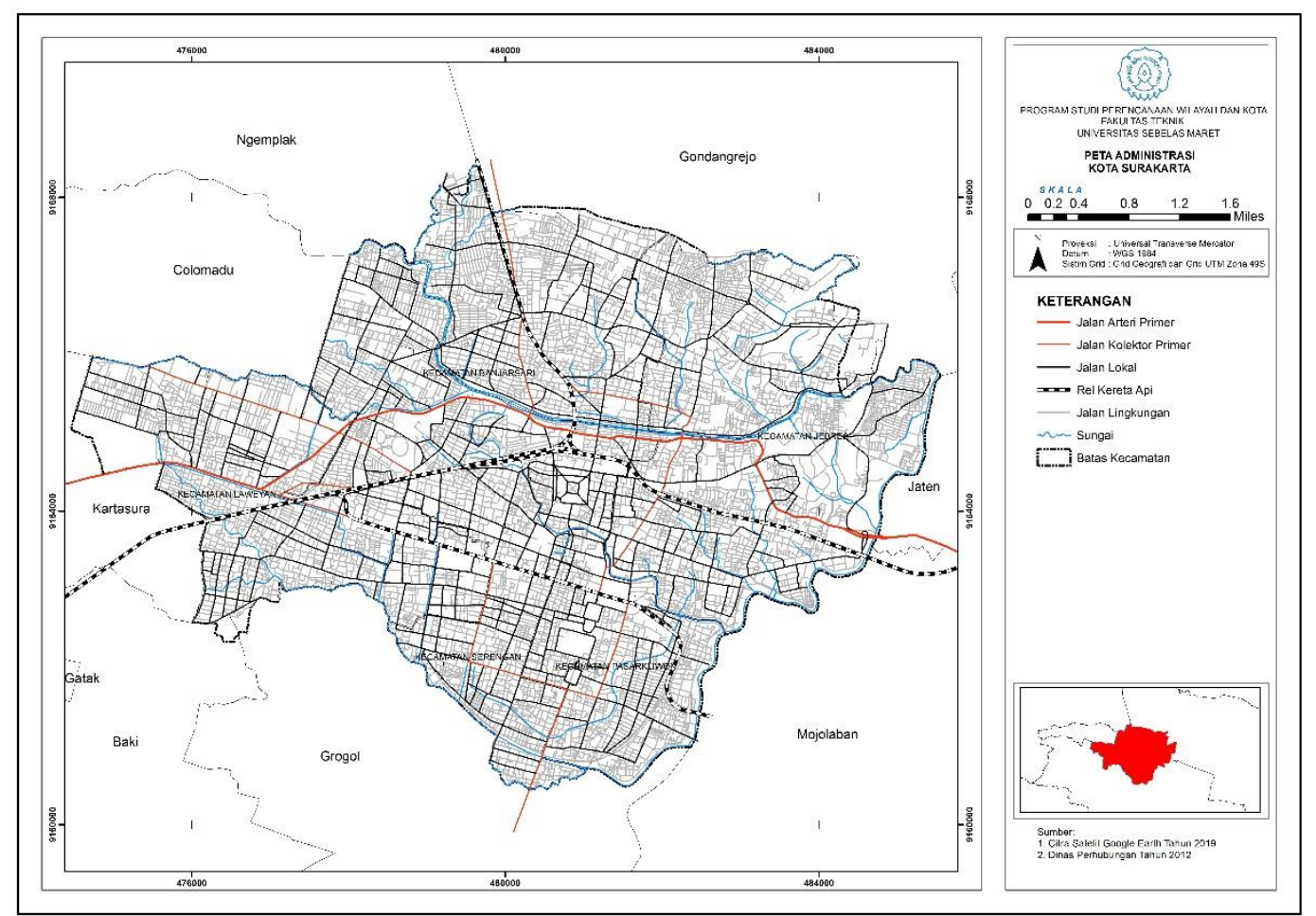

\section{Gambar 1. Peta Ruang Lingkup Wilayah Penelitian}

Tabel 1. Statistik Ruang Lingkup Wilayah Penelitian

\begin{tabular}{cc}
\hline \multicolumn{2}{c}{ Statistik Kota Surakarta } \\
\hline Luas Wilayah & $44,04 \mathrm{~km}^{2}$ \\
Jumlah Penduduk & 516.102 jiwa \\
Jumlah Kecamatan & 5 \\
Jumlah Kelurahan & 51 \\
\hline
\end{tabular}

Sumber: BPS Kota Surakarta, 2018

\subsection{TEKNIK ANALISIS PENELITIAN}

Teknik analisis yang digunakan dalam penelitian ini menggunakan analisis skoring dan analisis deskriptif. Analisis skoring digunakan untuk memberikan nilai atau skor kepada setiap sub-variabel untuk mengetahui kesesuain setiap komponen permukiman terhadap konsep layak huni. Skor yang diberikan menggunakan skala guttman dengan nilai maksimal 1 dan nilai minimal 0. Untuk menjabarkan data-data yang didapatkan dalam bentuk gambar, tabel, ataupun peta menggunakan teknik analisis deskriptif agar dapat dipahami dalam bentuk kalimat deskripsi.

\subsection{VARIABEL PENELITIAN}

Berikut merupakan variabel dan sub-variabel pada penelitian ini dapat dilihat pada Tabel 2.

\section{Tabel 2. Variabel Peneltian}

\begin{tabular}{|c|c|c|}
\hline No & Variabel & Sub-variabel \\
\hline 1 & Kualitas Bangunan Layak Huni & $\begin{array}{l}\text { Luas bangunan } \\
\text { Kondisi bangunan }\end{array}$ \\
\hline 2 & Ketersediaan Ruang Terbuka & $\begin{array}{l}\text { Ketersediaan RTH publik } \\
\text { Fungsionalitas RTH publik }\end{array}$ \\
\hline 3 & Ketersediaan Prasarana Penunjang & $\begin{array}{l}\text { Jalan lingkungan } \\
\text { Drainase lingkungan }\end{array}$ \\
\hline
\end{tabular}




\begin{tabular}{cll}
\hline No & \multicolumn{1}{c}{ Variabel } & \multicolumn{1}{c}{ Sub-variabel } \\
\hline & & Air bersih \\
& & Persampahan \\
& Pengelolaan air limbah \\
& & Pengamanan bahaya kebakaran \\
& & Jalur pedestrian yang aman \\
5 & Jalur Pedestrian & Kepadatan bangunan yang tidak tinggi \\
5 & Kepadatan Bangunan & Keterjangkauan biaya kebutuhan pokok \\
6 & Keterjangkauan Biaya Hidup & Ketersediaan transportasi umum \\
7 & Transportasi Umum & Aksesibilitas \\
& & Tarif transportasi umum \\
\hline
\end{tabular}

\section{HASIL DAN PEMBAHASAN}

Pada bagian ini akan membahas mengenai analisis data dari data-data yang sudah didapatkan dari kompilasi data-data yang tujuannya untuk mengetahui hasil analisis mengenai kesesuaian permukiman Kota Surakarta terhadap konsep livable settlement. Berikut merupakan hasil analisis data:

\subsection{GAMBARAN UMUM PERMUKIMAN DI KOTA SURAKARTA}

\subsubsection{Luas Bangunan}

Data mengenai luas bangunan rumah di permukiman Kota Surakarta dapat dilihat pada Gambar 2.

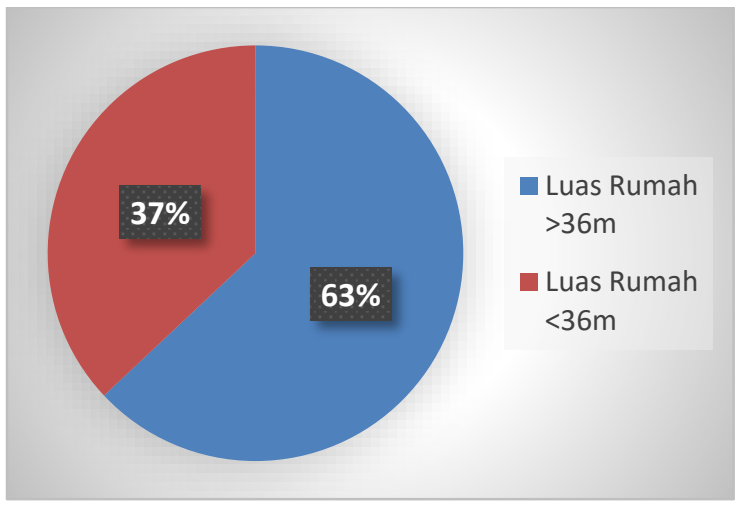

Sumber: BPS Kota Surakarta, 2018

\section{Gambar 2. Persentase Bangunan Berdasarkan Luas Bangunan}

Berdasarkan data yang diperoleh dari Dinas Perumahan, Kawasan Permukiman, dan Pertanahan Kota Surakarta yang mengacu data BPS diketahui bahwa jumlah bangunan rumah berdasar luas lantai yaitu sebanyak $63 \%$ rumah di Kota Surakarta memiliki luas lebih dari $36 \mathrm{~m}^{2}$, sedangkan sisanya sebanyak $37 \%$ bangunan rumah di Kota Surakarta memiliki luas kurang dari $36 \mathrm{~m}^{2}$ ataupun luas yang mendekati $36 \mathrm{~m}^{2}$.Sebanyak $37 \%$ bangunan rumah tersebut tersebar di seluruh permukiman Kota Surakarta.

\subsubsection{Kondisi Bangunan}

Data mengenai kondisi bangunan rumah di permukiman Kota Surakarta dapat dilihat pada Gambar 3. 


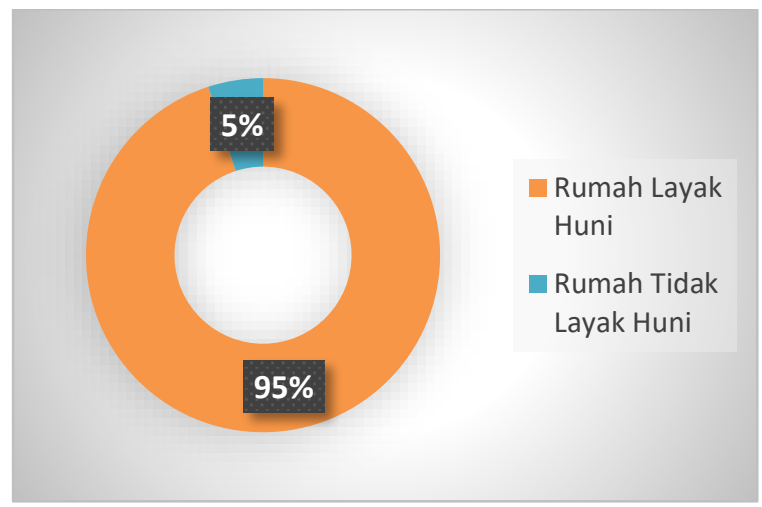

Sumber: Disperum KPP, 2018

\section{Gambar 3. Persentase Bangunan Berdasarkan Kondisi Bangunan}

Berdasarkan di atas diketahui bahwa sebagian besar bangunan rumah di Kota Surakarta sudah termasuk dalam rumah layak huni berdasarkan kondisi bangunan atau sebanyak 95\%. Sedangkan hanya sekitar $5 \%$ dari keseluruhan bangunan masih termasuk dalam rumah tidak layak huni. Tetapi tren rumah tidak layak huni cenderung turun setiap tahunnya karena pemerintah selalu membantu dan mengupayakan peningkatan kualitas dari rumah tidak layak huni tersebut.

\subsubsection{Ketersediaan Ruang Terbuka Hijau Publik}

Data eksisting ruang terbuka hijau publik di permukiman Kota Surakarta dapat dilihat pada Tabel 3.

Tabel 3. Eksisting Ruang Terbuka Hijau Publik

\begin{tabular}{clcc}
\hline No & \multicolumn{1}{c}{ Jenis RTH } & Luas (Ha) & Persentase \\
\hline 1 & Taman Kota & 11.33 & $0.257 \%$ \\
2 & Lapangan & 63.25 & $1.436 \%$ \\
3 & Jalur Hijau Jalan & 211.01 & $4.791 \%$ \\
& TPU (yang dikelola DKP) & 68.76 & $1.561 \%$ \\
4 & TPU (yang dikelola kelurahan) & 0.04 & $0.001 \%$ \\
& Sempadan Sungai & 77.61 & $1.762 \%$ \\
5 & Taman Balai Sungai & 0.15 & $0.003 \%$ \\
6 & Taman Bekas TPS & 0.11 & $0.002 \%$ \\
7 & Hutan Kota (Perwali) & 49.94 & $1.134 \%$ \\
8 & Tanah kosong diperuntukkan (Privat terukur) & 77.23 & $1.754 \%$ \\
9 & Taman Kelurahan & 1.83 & $0.042 \%$ \\
& Jumlah & $\mathbf{5 6 1 . 2 6}$ & $\mathbf{1 2 . 7 4 \%}$ \\
\hline
\end{tabular}

Sumber: Dokumen Peta Tutupan Vegetasi Kota Surakarta, 2015

Berdasarkan data di atas diketahui bahwa RTH Publik di Kota Surakarta masih di bawah standar yang berlaku yaitu hanya sebesar $12,74 \%$. Sementara RTH yang fungsinya untuk mengakomodasi kebutuhan masyarakat dan aksesnya dapat digunakan sewaktu-waktu yang berupa taman dan hutan kota jumlahnya masih di bawah dari $10 \%$. Menurut wawancara dengan Ibu Luluk selaku kepala pertamanan DLH Kota Surakarta bahwa banyak alih fungsi lahan RTH menjadi beberapa bangunan sehingga memungkinkan bila jumlah dari RTH itu sendiri mengalami penurunan jumlah di tahun 2019. Berikut merupakan peta perebaran RTH di Kota Surakarta pada Gambar 4. 


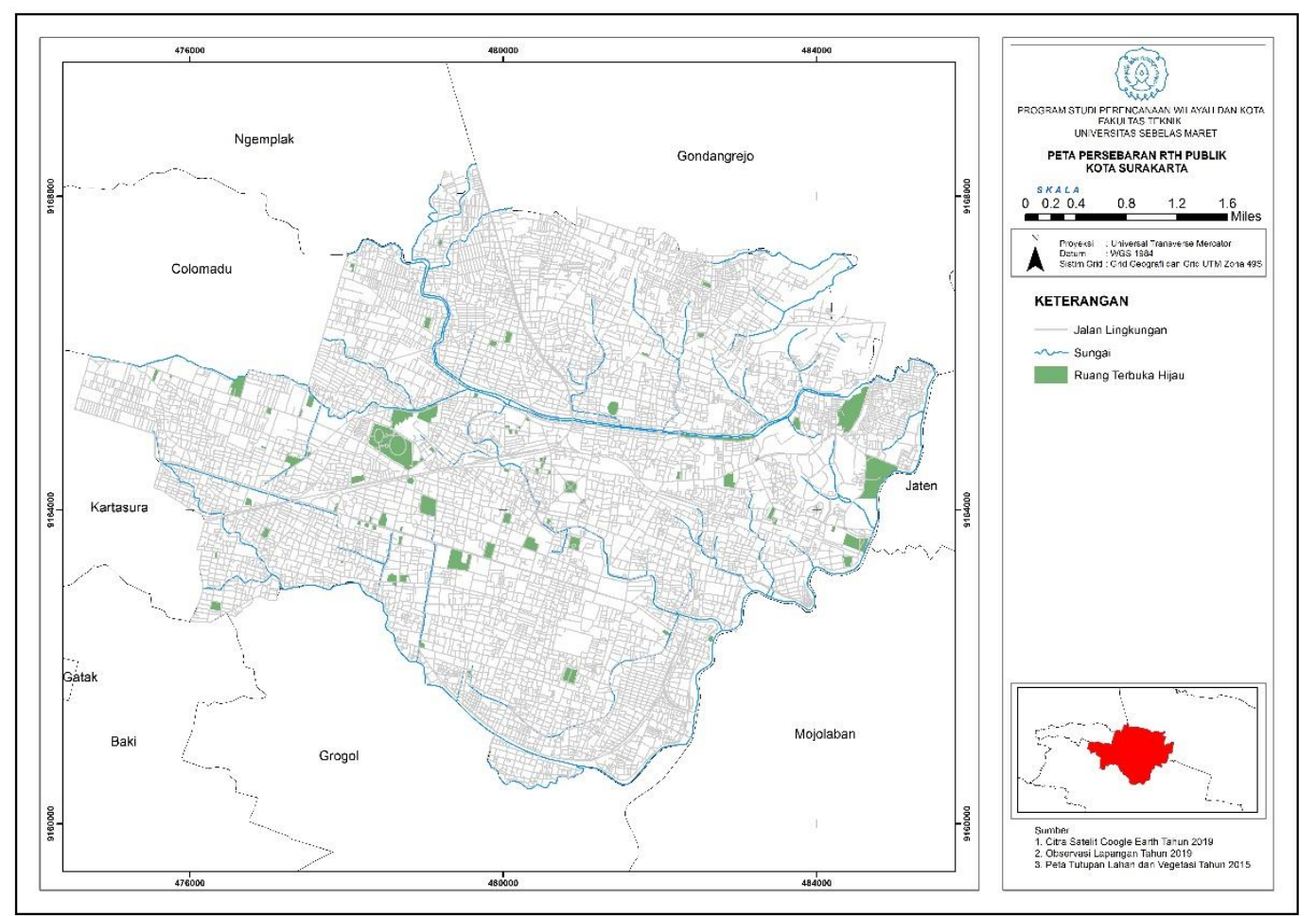

Gambar 4. Peta Persebaran Eksisting Ruang Terbuka Hijau Publik

\subsubsection{Fungsionalitas Ruang Terbuka Hijau Publik}

Berdasarkan kuesioner yang dibagikan ke masyarakat diketahui bahwa $64 \%$ pendapat masyarakat mengenai ruang terbuka hijau publik di Kota Surakarta masih sebagai sarana kesehatan dan rekreasi saja, sedangkan hanya 15\% menyatakan bahwa ruang terbuka hijau publik sudah memiliki fungsi yang lengkap dan dapat mengakomodasi kebutuhan masyarakat. Perlu adanya fungsi tambahan sebagai sarana pembelajaran yang dapat mengakomodasi kebutuhan anak-anak. Hanya ada beberapa taman bermain atau ruang terbuka hijau publik seperti di Taman Balaikambang, Taman Cerdas Jebres, taman bermain di Malabar Perumnas Mojosongo yang dilengkapi dengan sarana pembelajaran seperti perpustakaan, sanggar, taman baca.

\subsubsection{Jalan Lingkungan}

Menurut Statistik Kota Surakarta 2018 panjang jalan di Kota Surakarta yaitu sepanjang 710,73 km yang terbagi dalam 3 status jalan yaitu Jalan Nasional, Jalan Provinsi, dan Jalan Kota. Dari total panjang jalan sebanyak $72 \%$ jalan sudah dalam kondisi baik atau sekitar $514 \mathrm{~km}$, sedangkan sebanyak 28\% jalan masih dalam kondisi buruk atau sekitar $197 \mathrm{~km}$. Kemudian menurut Dinas Perumahan, Kawasan Permukiman, dan Pertanahan Kota Surakarta bahwa ketersediaan jalan tersebut sudah melayani seluruh permukiman yang berada di Kota Surakarta. Sehingga seluruh permukiman di Kota Surakarta sudah terhubung dan terintegrasi oleh jaringan jalan. Data mengenai kondisi dan peta jalan Kota Surakarta dapat dilihat pada Gambar 5 dan Gambar 6. 


\section{Jalan Kota Surakarta}

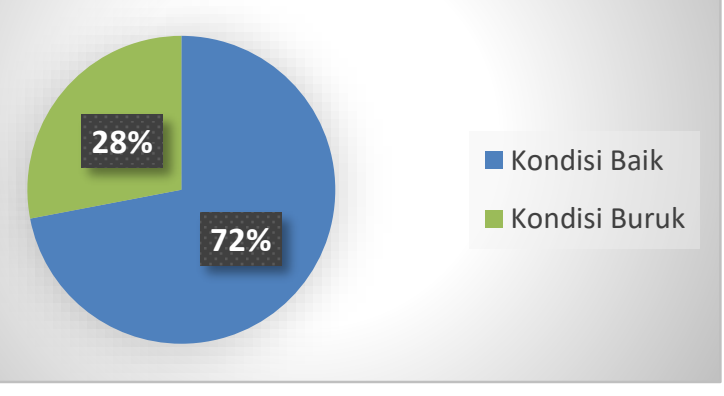

Sumber: BPS Kota Surakarta, 2018

Gambar 5. Persentase Kondisi Jalan Kota Surakarta

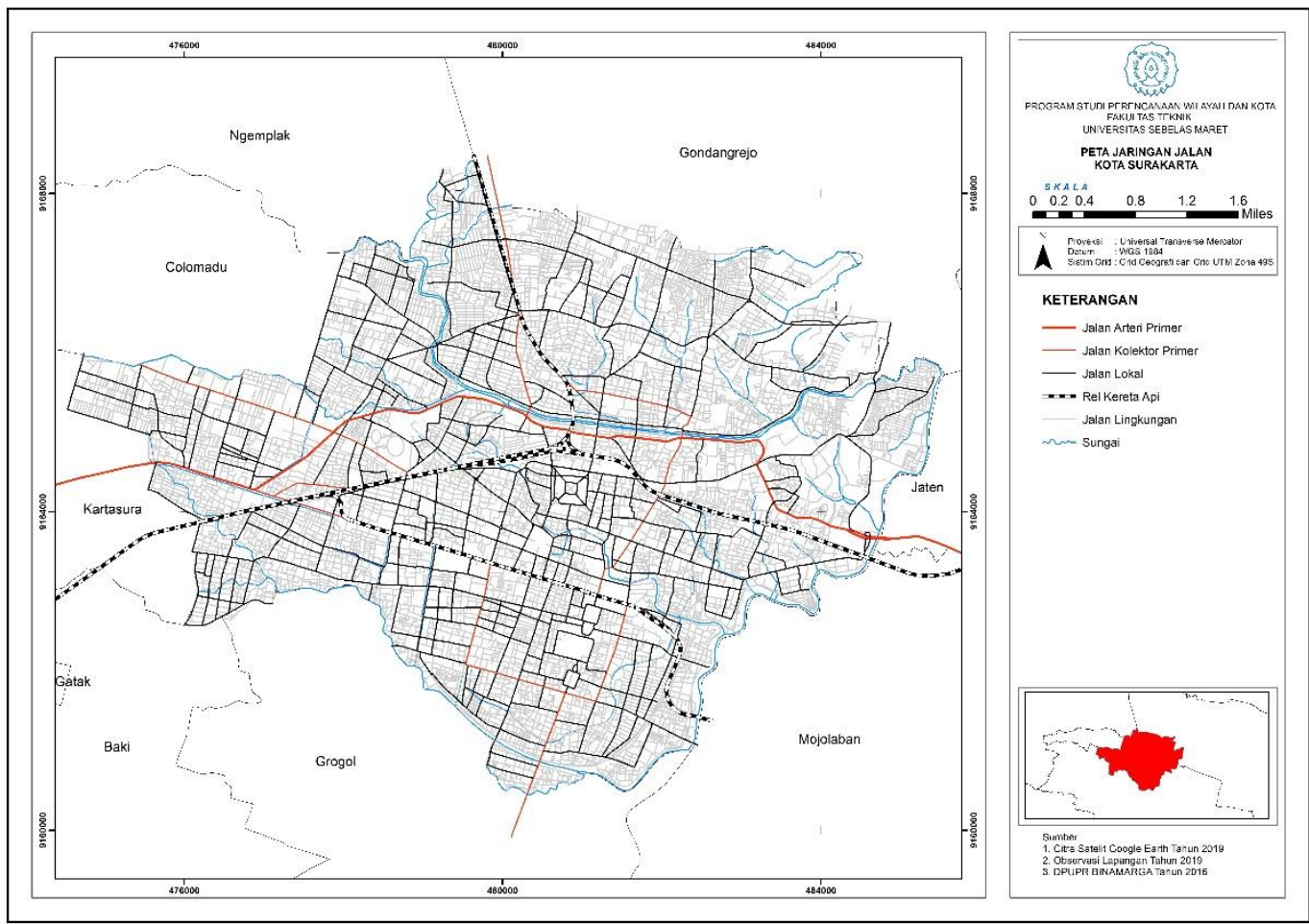

Sumber: DPUPR Kota Surakarta, 2019

Gambar 6. Peta Jalan Kota Surakarta

\subsubsection{Drainase Lingkungan}

Berdasarkan Gambar 7 diketahui bahwa drainase sekunder memiliki panjang 67,5 km dan drainase tersier sepanjang $455,3 \mathrm{~km}$. Bila dibandingkan dengan panjang jalan yang ada di Kota Surakarta yang memiliki panjang 710,73 km, sistem drainase di Kota Surakarta sudah menjangkau sekitar $74.13 \%$ dari total jalan tersebut. Karena pada dasarnya jaringan drainase merupakan pelengkap dari jaringan jalan dan ketersediannya harus saling melengkapi, hal ini juga untuk mengantisipasi timbulnya genangan pada jalan bila diakibatkan oleh curah hujan. 


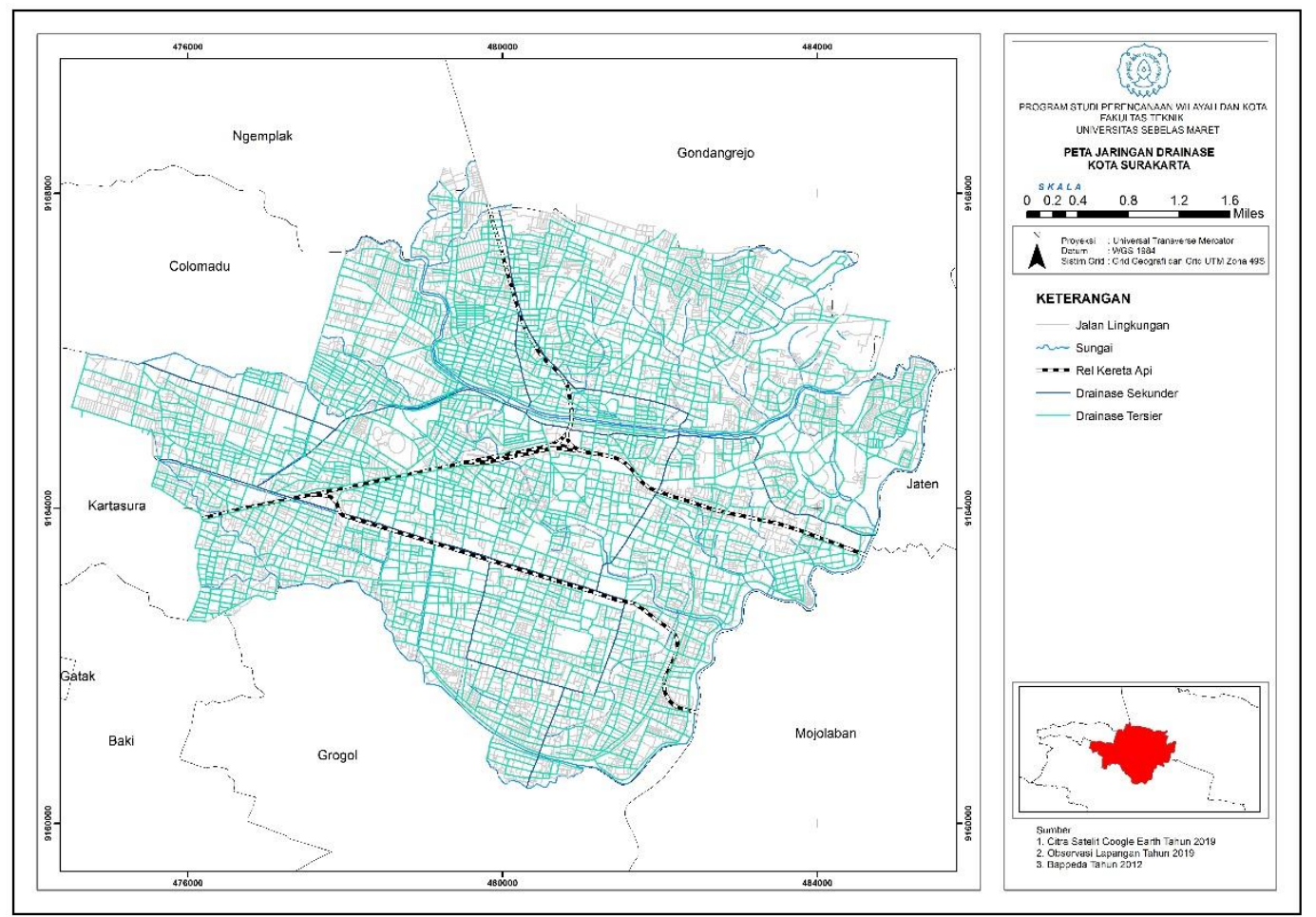

Sumber: Bappeda Kota Surakarta, 2018

Gambar 7. Drainase Kota Surakarta

\subsubsection{Air Bersih}

Menurut data PDAM (2019) total 58.231 sambungan rumah atau 307.445 jiwa dari 517.887 jiwa penduduk Kota Surakarta tahun 2019 telah terlayani oleh sambungan PDAM Kota Surakarta, atau sekitar 89,37\%. Sumber air berasal dari air baku mata air Cokrotulung sebesar 387 I/det, 20 buah sumur dalam yang aktif sebesar 346,14 I/dt dan dari 2 buah IPA (Instalasi Pengolahan Air Bengawan Solo) sebesar 166,65 I/dt. Bahkan perpipaan sudah menjangkau seluruh area Kota Surakarta termasuk bagian utara kota yang memiliki kontur tanah tinggi. Berikut merupakan jaringan perpipaan PDAM air bersih permukiman Kota Surakarta yang dapat dilihat pada Gambar 8.

\subsubsection{Persampahan}

Berdasarkan data diketahui bahwa TPS eksisting yang ada di Kota Surakarta memiliki tren penurunan dari tahun ke tahun. Hal ini dikarenakan Pemerintah Kota sudah mengganti kebijakan dari TPS bangunan menjadi TPS mobile. Hal ini bertujuan agar sampah tidak perlu menginap di TPS dan dapat menimbulkan bau bagi kawasan sekitar. Setiap kelurahan memiliki TPS mobile dengan jumlah yang berbeda sesuai banyaknya kebutuhan dan produksi sampah dengan alur pengangkutan sampah menuju TPA setiap hari, bahkan ada yang sampai dua sampai tiga kali dalam sehari. Prasarana penunjang persampahan lainnya antara lain bank sampah, tempat pemilahan sampah, gerobak dan truk sampah. Peta persebaran TPS eksisiting permukiman Kota Surakarta yang dapat dilihat pada Gambar 9. 


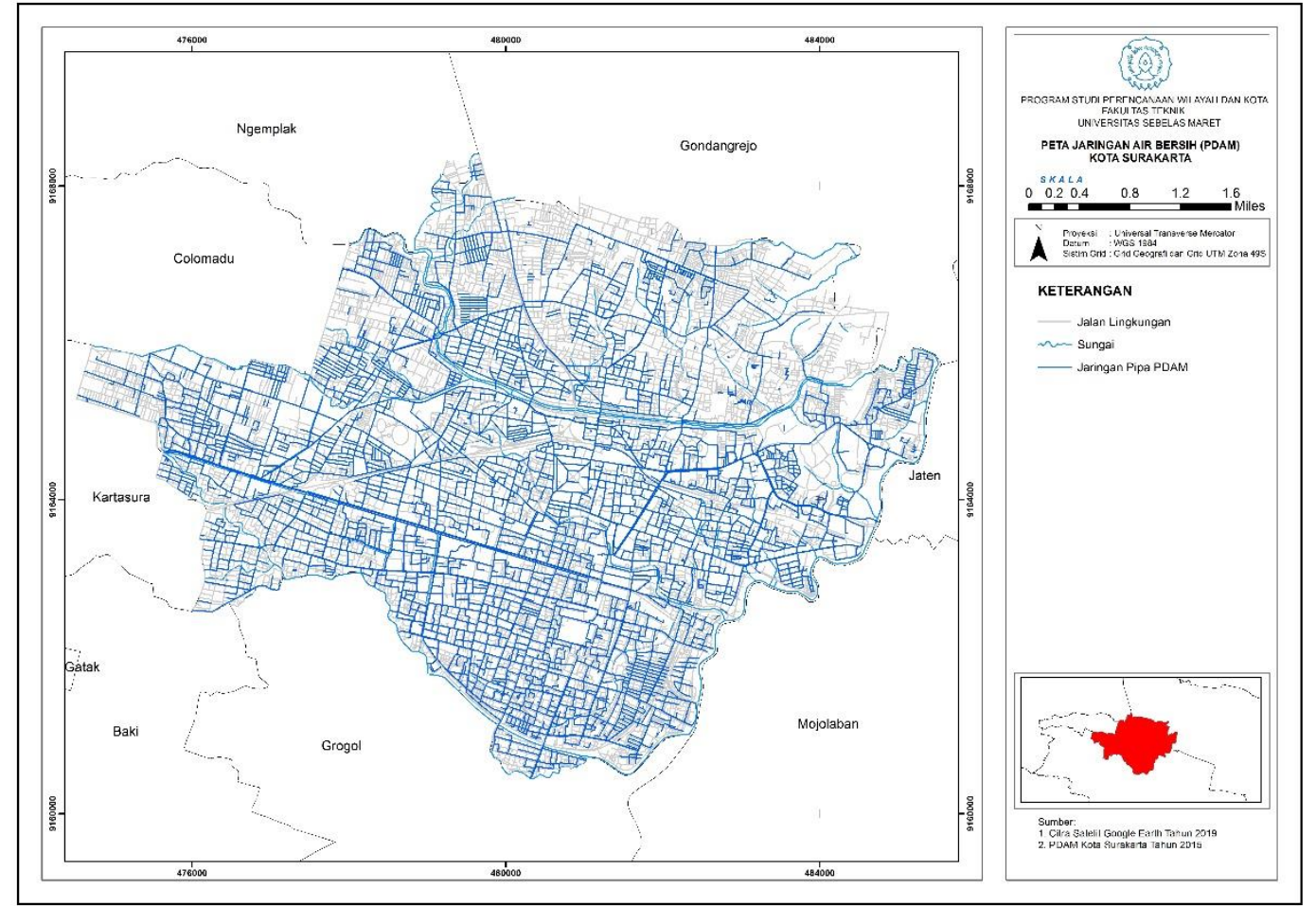

Sumber: PDAM Kota Surakarta, 2019

Gambar 8. Jaringan Air Bersih PDAM Kota Surakarta

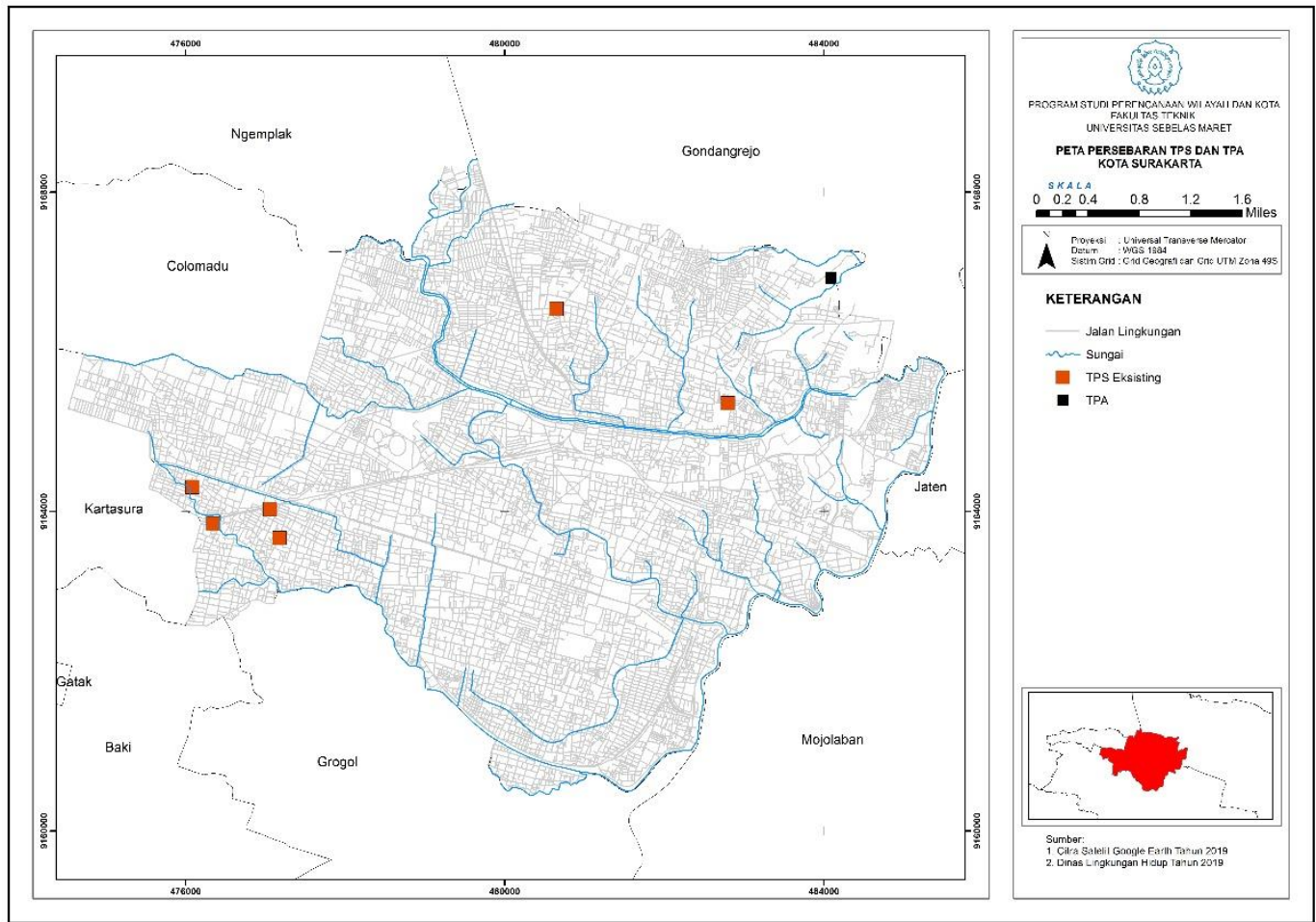

Sumber: Dinas Lingkungan Hidup Kota Surakarta, 2019

Gambar 9. Persebaran TPS dan TPA Eksisting Kota Surakarta 


\subsubsection{Pengelolaan Air Limbah}

Data mengenai pengelolaan air limbah di permukiman Kota Surakarta dapat dilihat pada Gambar 10 dan Gambar 11.

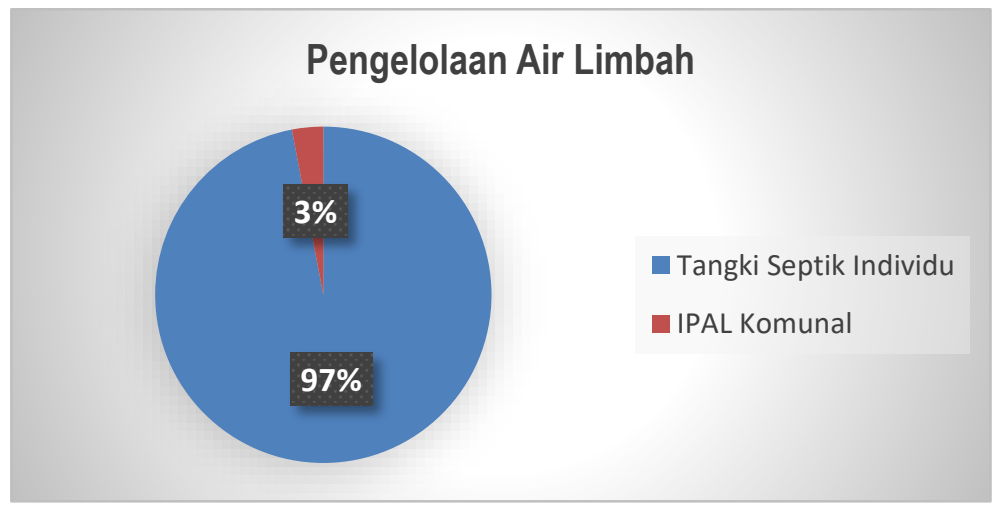

Sumber: Dinas Kesehatan Kota Surakarta, 2019; Disperum KPP, 2019

Gambar 10. Pengelolaan Air Limbah Kota Surakarta

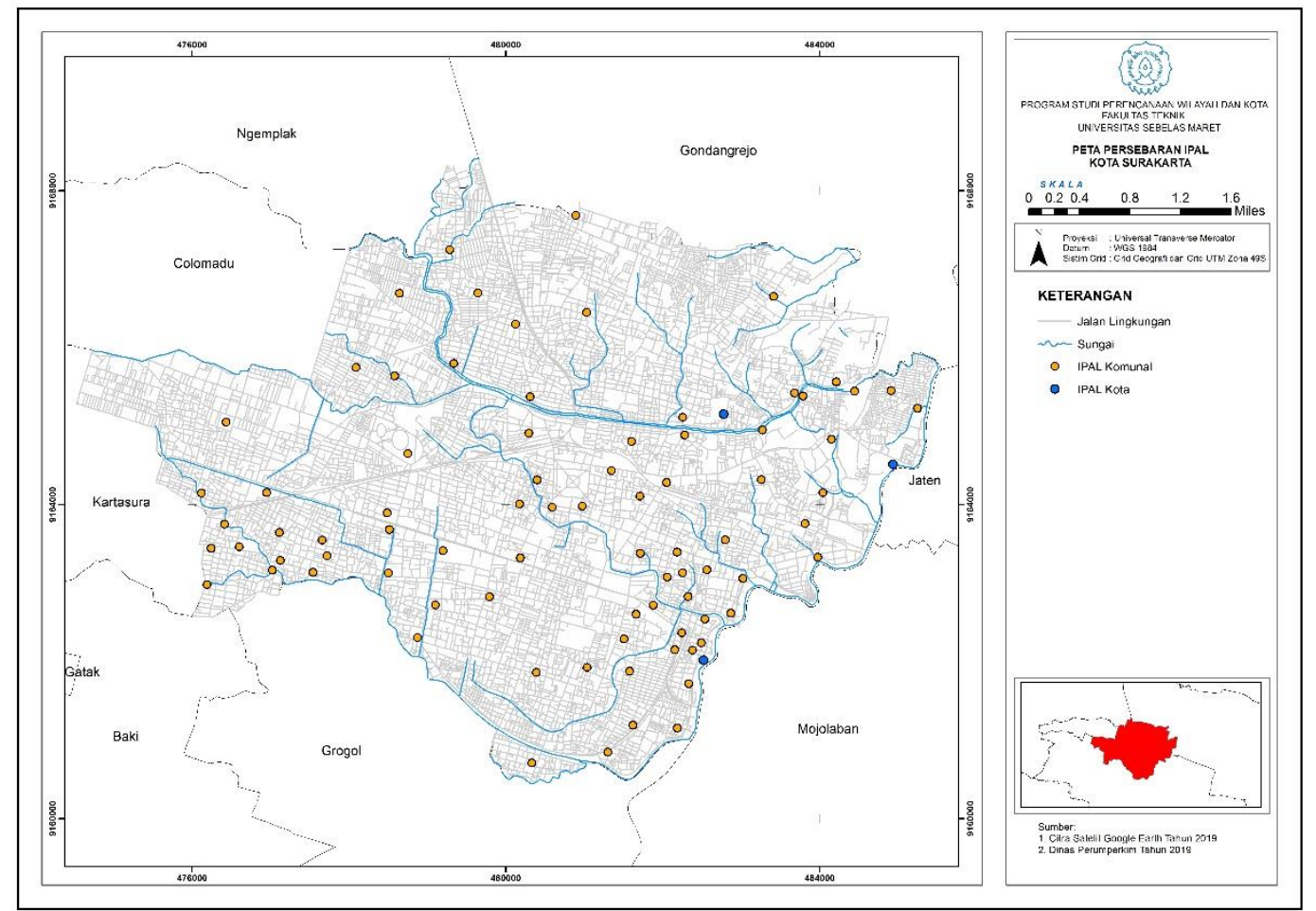

Sumber: Disperum KPP, 2019

Gambar 11. Peta Persebaran IPAL Kota Surakarta

Berdasarkan data di atas diketahui bahwa Kota Surakarta sudah memiliki 107 IPAL komunal, dan 3 IPAL Kota. Menurut hasil wawancara dengan Bapak Saryanto selaku Kepala bidang Perumahan di Dinas Perumahan, Kawasan Permukiman, dan Pertanahan Kota Surakarta mengenai pengelolaan air limbah dijelaskan bahwa sebagian lebih masyarakat atau sekitar 97\% menggunakan tangki septik pribadi untuk mengolah limbah mereka sebelum dibuang ke sungai. Kemudian dari IPAL komunal yang tersedia hanya dapat melayani $3 \%$ masyarakat saja karena jangkauan pelayanan masing-masing IPAL komunal hanya melayani 50 KK saja. IPAL kota yang ada di Surakarta sendiri berjumlah 3 dan berlokasi di Mojosongo, Pucangsawit, dan 
Semanggi. Kemudian berdasarkan wawancara dengan Kepala Seksi Kesehatan Lingkungan menjelaskan bahwa akses masyarakat Kota Surakarta terhadap sarana pengelolaan limbah sudah mencapai 100\% pada tahun 2018.

\subsubsection{Pengamanan Bahaya Kebakaran}

Berdasarkan data dari Dinas Pemadam Kebakaran (2019), diketahui bahwa di Kota Surakarta terdapat 48 hydrant yang berfungsi dengan baik. Hydrant ini berfungsi untuk menjaga ketersediaan supply air bagi mobil pemadam kebakaran ketika terjadi kebakaran. Bila dilihat dari peta keterjangkauan hydrant yang ada di Kota Surakarta, masih terdapat daerah yang belum terjangkau oleh hydrant. Dengan bantuan ArcGIS diketahui sebanyak $83,35 \%$ dari luas lahan di Kota Surakarta sudah terlayani atau terjangkau oleh hydrant yang artinya cakupannya sudah berada pada mayoritas lahan di Kota Surakarta. Kemudian 16,64\% dari luas Kota Surakarta masih belum terjangkau oleh hydrant, wilayah yang belum terjangkau hydrant antara lain: sebagian Kelurahan Jebres, sebagian Kelurahan Mojosongo, sebagian Kelurahan Kadipiro, sebagian Kelurahan Banjarsari, dan sebagian Kelurahan Banyuanyar. Sementara di Kota Surakarta sudah terdapat 4 pos pemadam kebakaran, dan rencananya masih terdapat 2 penambahan pos pemadam kebakaran baru lagi. Berikut adalah peta persebaran dan jangkauan hydrant Kota Surakarta yang dapat dilihat pada Gambar 12:

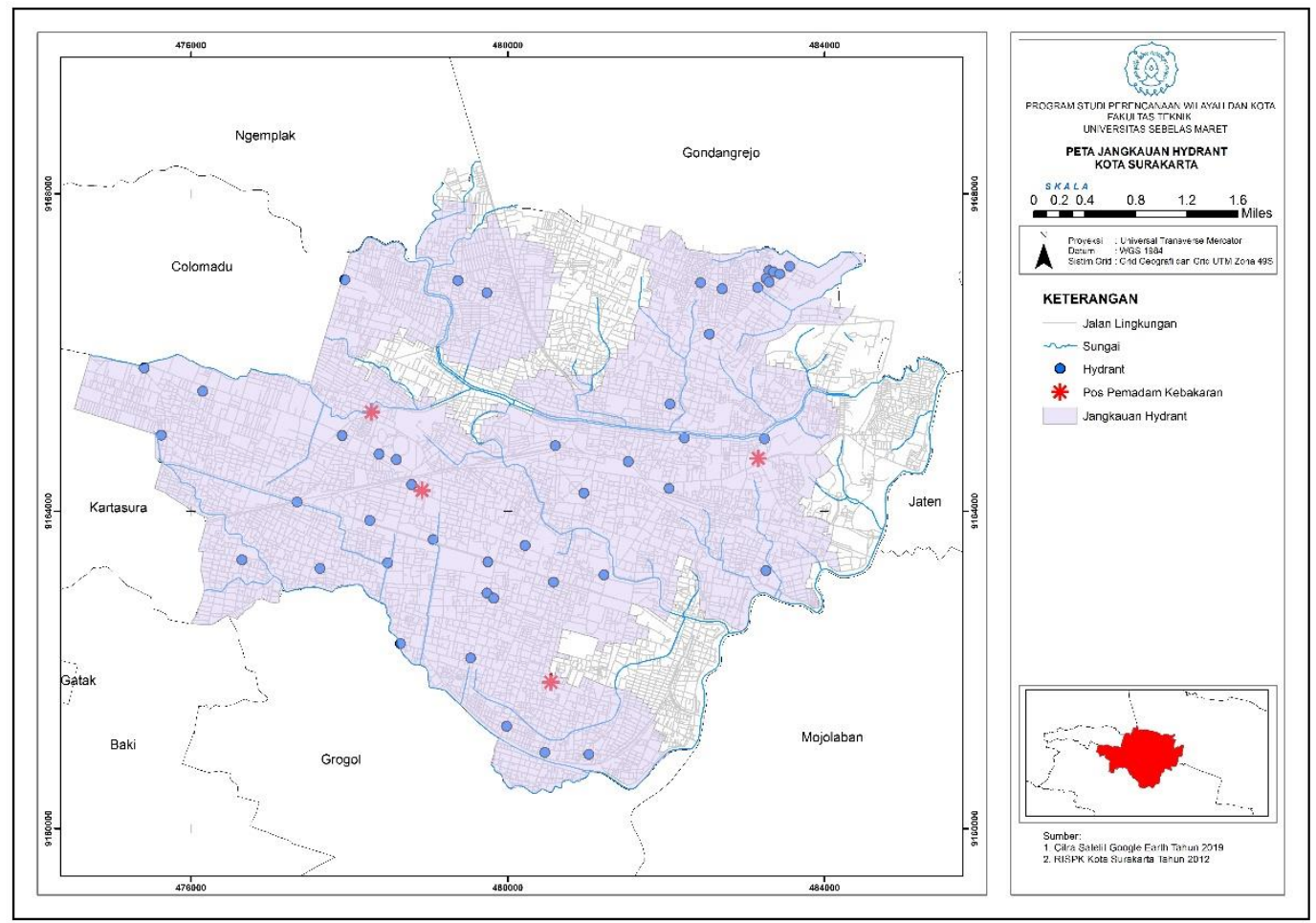

Sumber: Dinas Pemadam Kebakaran Kota Surakarta, 2019

Gambar 12. Jangkauan Persebaran Hydrant Kota Surakarta

\subsubsection{Jalur Pedestrian yang Aman}

Berdasarkan dari obervasi lapangan mengenai ketersediaan jalur pedestrian yang ada di Kota Surakarta, sebagian besar jalur pedestrian masih tergolong tidak aman atau belum aman yaitu sebesar $73 \%$ dari total ruas jalur pedestrian yang terdapat di Kota Surakarta. Bahkan di beberapa ruas jalan yang sudah terdapat jalur pedestrian masih belum terdapat komponenkomponen jalur pedestrian untuk mendukung keamanan dari pengguna pedestrian tersebut. Kemudian dari keseluruhan jalur pedestrian yang ada sebagian besar sudah dilengkapi pembatas jalan dan lampu penerangan jalan. Kemudian hanya sedikit dari beberapa jalur pedestrian yang dilengkapi detacble warning \& curb ramp, padahal komponen itu termasuk bagian penting untuk mengakomodasi kebutuhan kaum difabel. Lalu jalur pedestrian yang sudah memenuhi standar keamanan adalah sebanyak $27 \%$ dari total jalur pedestrian yang terdapat di Kota Surakarta. Berikut adalah peta persebaran jalur pedestrian Kota Surakarta berdasarkan klasifikasi aman dan tidak aman dapat dilihat pada Gambar 13: 


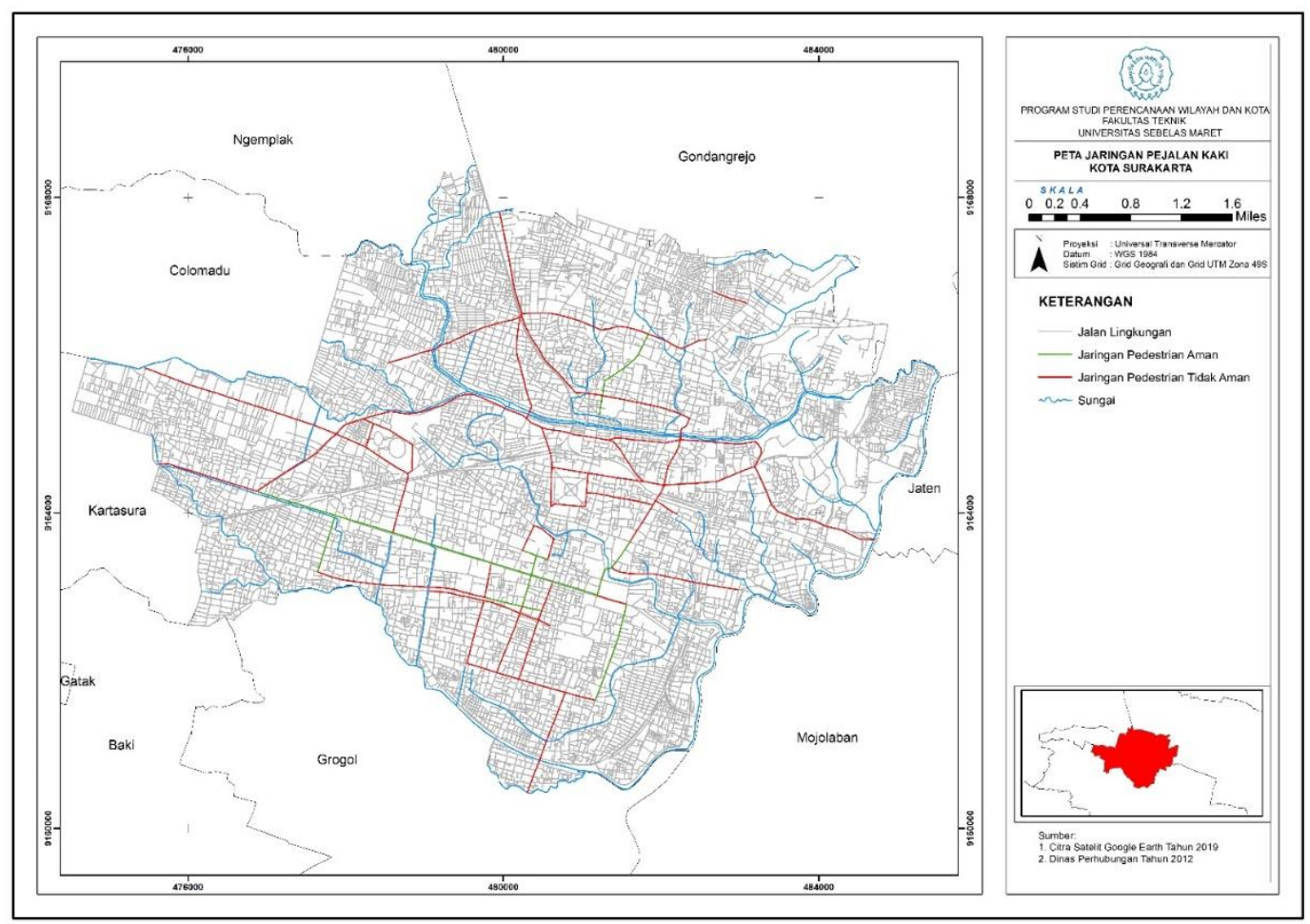

Gambar 13. Persebaran Jalur Pejalan Kaki Kota Surakarta

\subsubsection{Kepadatan Bangunan yang Tidak Tinggi}

Berdasarkan hasil perhitungan di atas diketahui bahwa kepadatan bangunan permukiman Kota Surakarta adalah sebesar 50 bangunan/ha. Kemudian bila mengacu pada Keputusan Menteri PU No. 378/KPTS/1987 Lampiran No 22 tentang klasifikasi kepadatan bangunan maka dengan kepadatan sebesar 50 bangunan/ha termasuk dalam kategori kepadatan sedang yang artinya permukiman Kota Surakarta masih dalam kategori kepadatan yang tidak tinggi. Sehingga dari kepadatan bangunan Kota Surakarta yang masih tergolong sedang dapat dimanfaatkan oleh masyarakat untuk beraktivitas secara leluasa sehingga dapat meningkatkan tingkat kenyamanan dan layak huni bagi penduduk.

\subsubsection{Keterjangkauan Biaya Pokok}

Berdasarkan hasil kuesioner dengan masyarakat permukiman Kota Surakarta diketahui bahwa sebanyak $64 \%$ di antaranya menyatakan bahwa pendapatan total yang diterima oleh keluarga lebih besar dari pengeluaran sehingga cukup untuk membiayai kebutuhan pokok sehari-hari. Tetapi $36 \%$ menyatakan bahwa pendapatan yang diterima masih belum atau lebih sedikit dari pengeluaran sehingga belum cukup untuk memenuhi kebutuhan keluarga mereka

\subsubsection{Ketersediaan Transportasi Umum}

Transportasi umum yang berada di Kota Surakarta meliputi Batik Solo Trans dan angkutan umum kota. Untuk rute BST memiliki start awal di Terminal Palur Karanganyar dengan tujuan Bandara Adi Soemarmo dan Terminal Sukoharjo. Rute yang dilalui sendiri meliputi mayoritas jalur perhubungan Kota Surakarta bagian selatan. Sedangkan untuk angkutan umum Kota Surakarta memiliki jalur yang lebih beragam dan melayani dari utara dan selatan kota bahkan juga timur dan barat kota. Berikut merupakan peta rute Batik Solo Trans (BST) dan angkutan umum kota dapat dilihat pada Gambar 14 dan Gambar 15. 


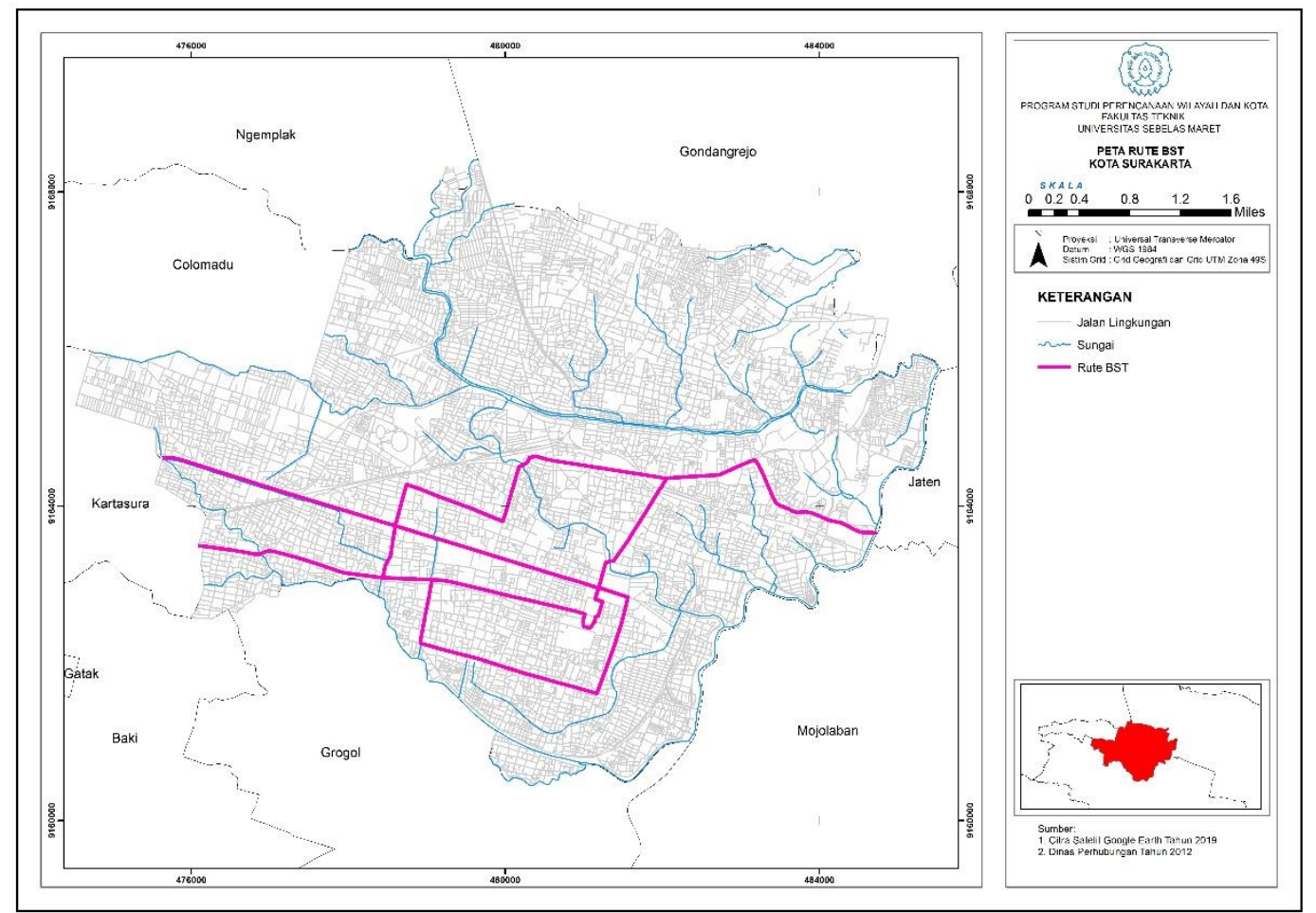

Sumber: Dinas Perhubungan, 2012

Gambar 14. Peta Rute BST Kota Surakarta

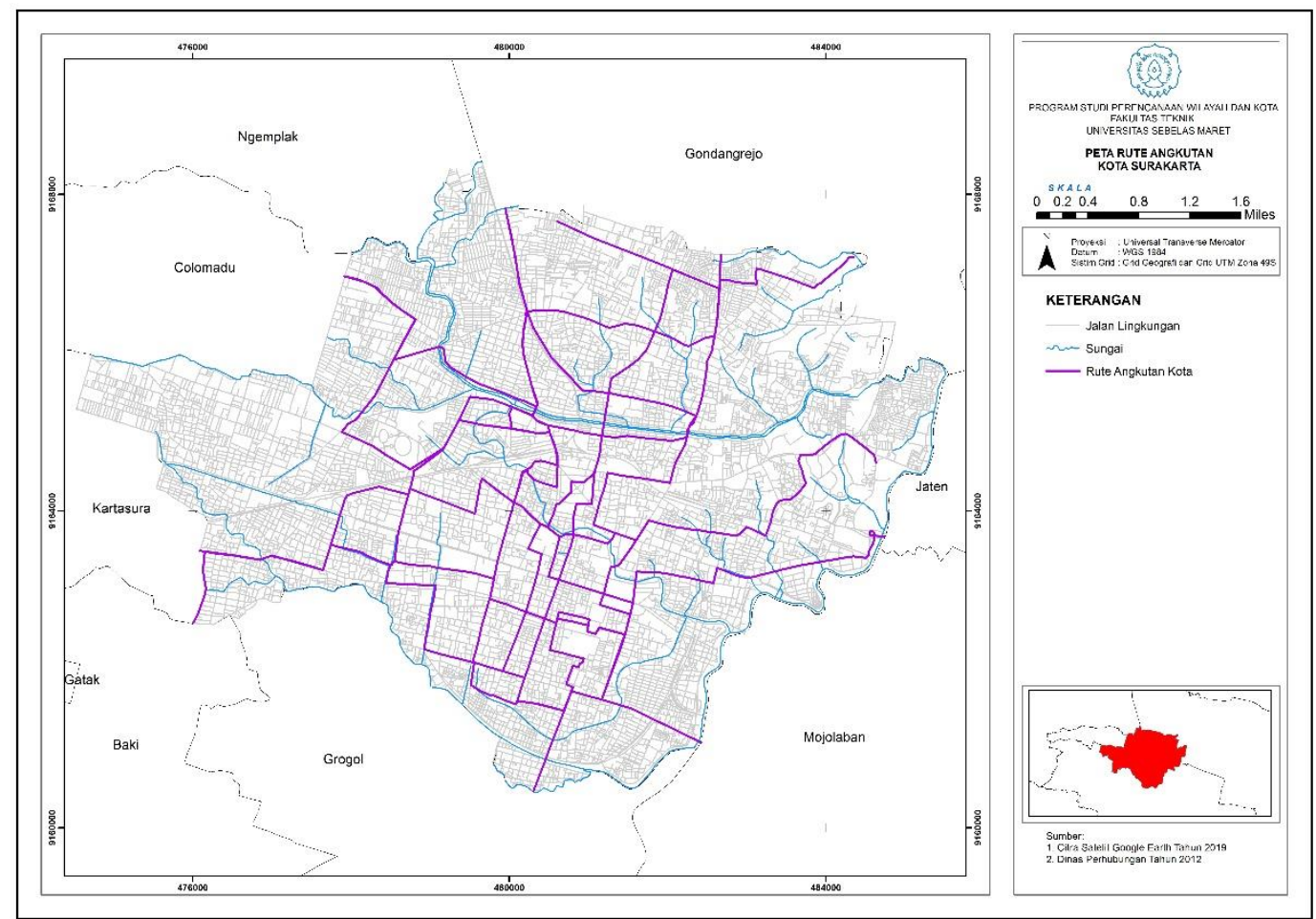

Sumber: Dinas Perhubungan, 2012

Gambar 15. Peta Rute Angkutan Kota Surakarta 


\subsubsection{Aksesibilitas}

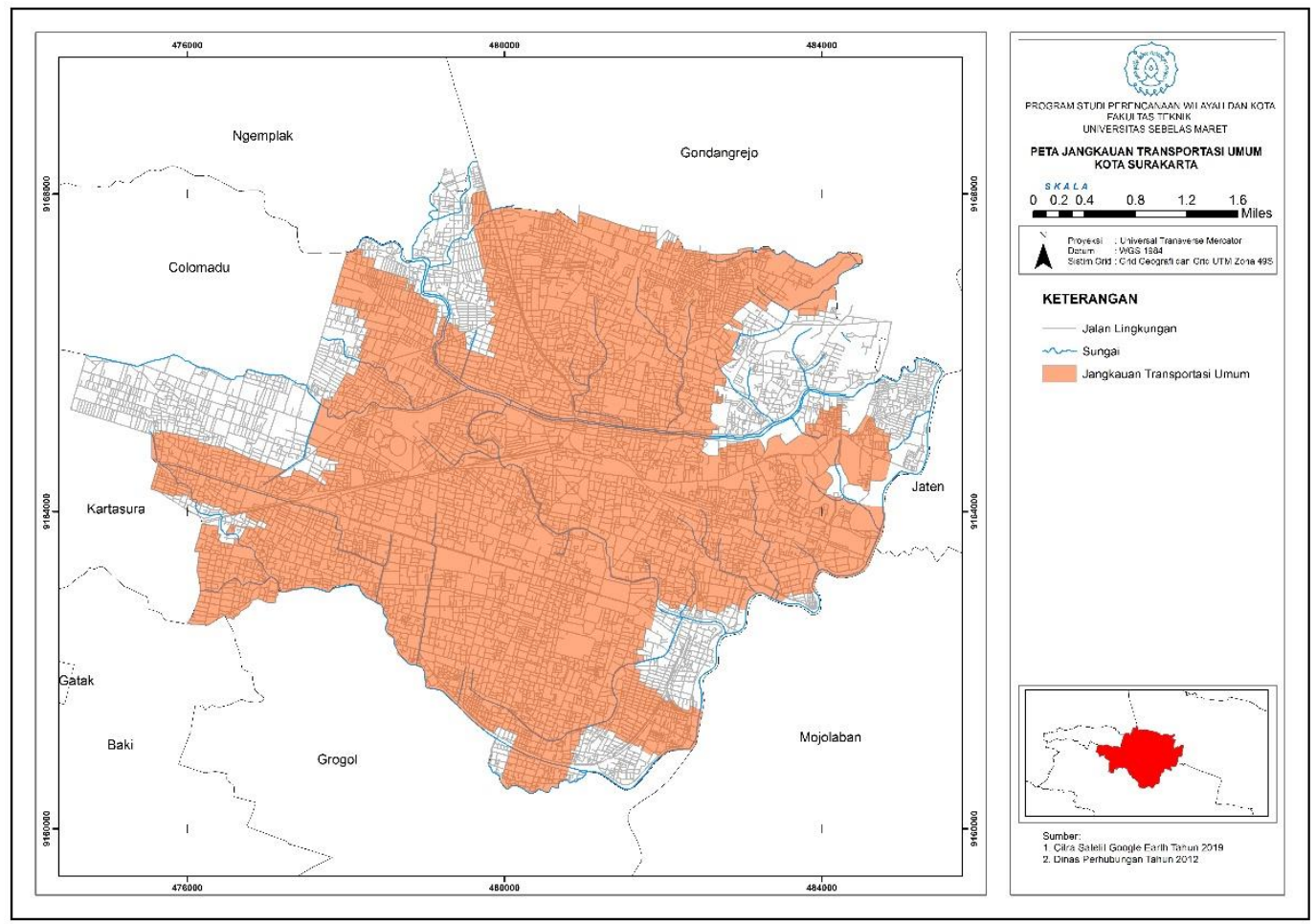

Gambar 16. Jangkauan Transportasi Umum Kota Surakarta

Kemudian setelah melihat ketersediaan transportasi, hal lain juga mempertimbangkan kemudahan untuk memperoleh transportasi umum tersebut. Fakta lapangan mengatakan bahwa masih terdapat rumah-rumah warga yang memiliki tingkat aksesibiltas sulit dalam mencapai transportasi umum jika harus berjalan dari rumah masing-masing. Dari Gambar 18 diketahui masih terdapat red-zone atau daerah yang belum terjangkau transportasi umum, dengan banuan software ArcGIS diketahui sebanyak 1043,16 Ha atau sekitar 23,70\% lahan di Kota Solo yang belum terjangkau moda transprotasi umum. Sedangkan daerah yang sudah terjangkau oleh moda transportasi umum adalah sebanyak $76.30 \%$ meliputi seluruh kota (lihat Gambar 16).

\subsubsection{Tarif Transportasi Umum}

Tarif transportasi umum juga menjadi salah satu pertimbangan bagi konsep livable settlement karena keterjangkauan tarif dapat sebagai pertimbangan masyarakat untuk menggunakan transportasi umum, dengan tarif transportasi yang terjangkau akan mendorong penggunaan transportasi umum. Menurut Dinas Perhubungan tarif transportasi umum pada Batik Solo Trans (BST) sekarang sebesar Rp 4.500,00 untuk masyarakat umum (sekali jalan), sedangkan untuk pelajar hanya sebesar Rp 2.500,00 (sekali jalan). Untuk angkutan umum penentuan biaya relatif tergantung jauh tidaknya rute, tetapi rata-rata dikisaran Rp 5.000,00 untuk masyarakat umum, sedangkan untuk pelajar dikisaran Rp 2.000,00. Lalu terdapat wacana di tahun 2018/2019 bahwa Pemerintah Kota Surakarta akan menggratiskan angkutan umum bagi para pelajar, hal ini berfungsi untuk meredam tingginya penggunaan transportasi online yang berada pada Kota Surakarta.

\subsection{KESESUAIAN KOMPONEN PERMUKIMAN TERHADAP KONSEP LAYAK HUNI}

Berdasarkan kompilasi dan analisis data yang telah dilakukan maka dapat diketahui tingat kesesuaian permukiman Kota Surakarta terhadap konsep livable settlement dari Tabel 4. 
Tabel 4. Kesesuaian Komponen Permukiman Kota Surakarta

\begin{tabular}{|c|c|c|c|c|}
\hline Variabel & Sub-variabel & Standar Minimum & $\begin{array}{l}\text { Persentase } \\
\text { Pencapaian }\end{array}$ & Skor \\
\hline \multirow{6}{*}{$\begin{array}{l}\text { Kualitas bangunan } \\
\text { layak huni } \\
\text { Ketersediaan Ruang } \\
\text { Terbuka }\end{array}$} & Luas bangunan & $76 \%$ & $63 \%$ & 0 \\
\hline & Kondisi bangunan & $76 \%$ & $95 \%$ & 1 \\
\hline & Ketersediaan RTH Publik & $20 \%$ & $12,74 \%$ & 0 \\
\hline & Fungsionalitas RTH Publik & $50 \%$ & $15 \%$ & 0 \\
\hline & Jalan lingkungan & $70 \%$ & $72 \%$ & 1 \\
\hline & Drainase lingkungan & $85 \%$ & $74 \%$ & 0 \\
\hline \multirow{4}{*}{$\begin{array}{l}\text { Terdapat prasarana } \\
\text { penunjang }\end{array}$} & Air bersih & $85 \%$ & $89 \%$ & 1 \\
\hline & Persampahan & $80 \%$ & $100 \%$ & 1 \\
\hline & Pengelolaan air limbah & $85 \%$ & $100 \%$ & 1 \\
\hline & $\begin{array}{l}\text { Pengamanan bahaya } \\
\text { kebakaran }\end{array}$ & $50 \%$ & $83 \%$ & 1 \\
\hline Jalur pedestrian & Jalur pedestrian yang aman & $85 \%$ & $27 \%$ & 0 \\
\hline Kepadatan bangunan & $\begin{array}{l}\text { Kepadatan bangunan yang } \\
\text { tidak tinggi }\end{array}$ & 60 bangunan/ha & 50 bangunan/ha & 1 \\
\hline $\begin{array}{l}\text { Keterjangkauan biaya } \\
\text { hidup }\end{array}$ & $\begin{array}{l}\text { Biaya hidup yang } \\
\text { terjangkau }\end{array}$ & $50 \%$ & $64 \%$ & 1 \\
\hline \multirow{3}{*}{ Transportasi umum } & $\begin{array}{l}\text { Ketersediaan transportasi } \\
\text { umum }\end{array}$ & $\begin{array}{c}\text { Terdapat } \\
\text { transportasi umum }\end{array}$ & $\begin{array}{l}\text { Terdapat } 2 \text { jenis } \\
\text { transportasi umum }\end{array}$ & 1 \\
\hline & Aksesibilitas & $50 \%$ & $76 \%$ & 1 \\
\hline & $\begin{array}{l}\text { Tarif Transportasi umum } \\
\text { Total }\end{array}$ & $50 \%$ & $97 \%$ & $\begin{array}{c}1 \\
11\end{array}$ \\
\hline
\end{tabular}

Setelah mendapat skor dari tiap-tiap sub-variabel berdasarkan parameter yang berada di variabel tersebut, total skor tersebut dijumlahkan agar mendapatkan kesimpulan seberapa besar tingkat kesesuaian permukiman Kota Surakarta terhadap konsep livable settlement. Berikut adalah perhitungan skornya:

$$
\begin{gathered}
\text { Skor }=\frac{\text { Total skor }}{\text { Jumlah skor maksimal }} \times 100 \% \\
\text { Skor }=\frac{11}{16} \times 100 \%=68,75 \%
\end{gathered}
$$

Dari hasil perhitungan tersebut, diketahui bahwa kesesuaian permukiman Kota Surakarta terhadap konsep livable settlement sebesar $68,75 \%$ yang berarti permukiman Kota Surakarta mendekati sesuai dengan konsep livable settlement.

\section{KESIMPULAN}

Permukiman di Kota Surakarta berdasarkan hasil penelitian ini memiliki tingkat kesesuaian $68,75 \%$ yang berarti sudah termasuk dalam permukiman yang mendekati sesuai dengan prinsip permukiman yang layak huni. Hal ini dikarenakan beberapa komponen permukiman yang sudah sesuai aspek layak huni di antaranya kondisi bangunan, jalan lingkungan, air bersih, persampahan, pengelolaan air limbah, pengamanan bahaya kebakaran, kepadatan bangunan yang tidak tinggi, biaya hidup yang terjangkau, ketersediaan transportasi umum, aksesibilitas, dan tarif transportasi umum. Di samping komponen permukiman yang sudah sesuai dengan aspek layak huni, ternyata masih terdapat beberapa komponen permukiman belum sesuai aspek layak huni di antaranya: luas bangunan, ketersediaan dan fungsionalitas ruang terbuka hijau, jalur pedestrian yang tidak aman, dan kuantitas drainase lingkungan yang belum memadai

Skor yang paling rendah pada komponen permukiman adalah pada jalur pedestrian atau jaringan pejalan kaki merupakan salah satu aspek penting karena ketersediaannya dapat mempermudah mobilisasi pejalan kaki untuk berpindah dari satu tempat ke tempat lain. Kriteria keamanan jaringan pejalan kaki juga dapat menjamin keselamatan pengguna pejalan kaki dari pengguna jalan lain. Begitu juga dengan ketersediaan ruang terbuka hijau yang ketersediaannya masih di bawah standar 
penyediaan ruang terbuka hijau publik di area perkotaan, ketersediaannya dapat menunjang fungsinya sebagai RTH dan dapat berguna untuk mengakomodasi kebutuhan masyarakat.

\section{DAFTAR PUSTAKA}

Dinas Pemadam Kebakaran Kota Surakarta. (2018). Rencana Induk Sistem Proteksi Kebakaran Tahun 2018

Direktorat Jenderal Cipta Karya. (2016). Surat Edaran Nomor: 40/SE/DC/2016 Tentang Pedoman Umum Program Kota Tanpa Kumuh (KOTAKU). Diakses dari http://kotaku.pu.go.id/view/6900/surat-edaran-djck-no-40-se-dc-2016-tentang-pedoman-umum-programkotaku

Furlan, R. (2015). Livability and Social Capital in West Bay, The New Business Precinct of Doha. Arts and Social Sciences Journal, 6(3), 1-11. DOI: $10.4172 / 2151-6200.1000116$

Furlan, R. (2016). Urban Design and Social Liveability: The Revitalization of the Corniche in Doha. American Journal of Environmental Engineering, 6(3), 73-87. DOI: 10.5923/j.ajee.20160603.01.

Helena, A. C., \& Hidayati, I. N. (2016). Pemanfaatan Citra Quickbird dan SIG Untuk Pemetaan Tingkat Kenyaman Permukiman Di Kecamatan Semarang Barat dan Kecamatan Semarang Utara. MGI, 30(1), 1-8. DOI: 10.22146/mgi.15600

Hendarti, H. (2006). Perananan Biaya Sosial dalam Meningkatkan Kinerja Sosial dan Keuangan Perusahaan High and Low Profile. Journal The Winners, 7(2), 128-143. DOI: 10.21512/tw.v7i2.617

Heylen, K. (2006). Liveability in Social Housing: Three Case in Flanders. ENHR International Conference, 1-23. Diakses dari https://pdfs.semanticscholar.org/f63e/8e5ea69101d102125368aecf2eb0c8bc51c8.pdf

Ikatan Ahli Perencana (IAP). (2018, April 3). Launching Indonesia Most Livable City Index (MLCI) 2017. Diakses dari http://iapindonesia.org/news/5ee0b863140bc31fdd46313a

Khadiyanto, P., Soetomo, S. \& Hadi, S. P. (2015). Settlement Adaptation on a Seawater Tide Overflow Area, at The North Part of Semarang, Indonesia, Journal of Flood Risk Management, 10(4), 535-545. DOI: 10.1111/ffr3.12167

Kementrian Pekerjaan Umum dan Perumahan Rakyat. 2007. RPIJM Rencana Program Investasi Jangka Menengah) dari Direktorat Jenderal Cipta Karya Departemen Pekerjaan Umum 2006-2010. Jakarta. Diakses dari: http://ciptakarya.pu.go.id/dok/rpijm/01.\%20PENJELASAN\%20UMUM\%2017-09-2007.pdf

Luhst, K. M. (1997). Real Estate Valuation; Principles and Applications. USA: Time Mirror Education Group.

Maslow, A. (1994). Motivasi dan Kepribadian (Teori motivasi dengan pendekatan hierarki kebutuhan manusia). Jakarta: PT. PBP.

PDAM Kota Surakarta. (2019). Komunikasi Personal

Peraturan Menteri Pekerjaan Umum Nomor: 22/PRT/M/2008 Tentang Pedoman Teknis Pengadaan, Pendaftaran, Penetapan Status, Penghunian, Pengalihan Status, dan Pengalihan Hak Atas Rumah Negara. Diakses dari http://setjen.kemenkeu.go.id/api/Medias/642e53bb-e15e-469a-b5ea-fe58d3571cac

Perry, C. (1929). The Neighborhood Unit. New York: Thoemmes Press.

Putri, H. \& Jamal, A. (2014). Faktor-Faktor yang Mempengaruhi Pemilihan Lokasi Perumahan di Kota Banda Aceh, Jurnal Ekonomi dan Kebijakan Publik Indonesia, 1(2), 55-61. Diakses dari http://jurnal.unsyiah.ac.id/EKaPl/article/view/3708

Raditya, D. (2011, September 27). Pengertian Umum tentang Perencanaan Wilayah dan Kota, Wordpress. Diakses dari https://dennyraditya73.wordpress.com/2011/09/27/pengertian-umum-tentang-perencanaan-wilayah-dan-kota/

Silas, J. \& Ernawati, R. (2013). Liveability of Settlements by People in the Kampung of Surabaya. International CIB World, 2. Diakses dari https://www.irbnet.de/daten/iconda/CIB_DC27199.pdf

SNI 03-1727-1989 tentang Pedoman Perencanaan Pembebanan Untuk Rumah dan Gedung. Diakses dari https://kupdf.net/download/sni03-1727-1989-ppurg_58a6fad56454a7310cb1e8d1_pdf

Tarigan, R. (2012). Perencanaan Pengembangan Wilayah. Jakarta: Bumi Aksara. Jakarta: Bumi Aksara.

Undang-Undang Nomor 1 Tahun 2011 Tentang Perumahan dan Kawasan Permukiman. Diakses dari https://www.bphn.go.id/data/documents/11uu001.pdf 